DOI: 10.1515/pof-2016-0008

VOLUME 8, ISSUE 2, 2016

ISSN: 2036-5438

\title{
A Sustainable European Union Own Resources System
}

by

\author{
Maciej Cieslukowski*
}

Perspectives on Federalism, Vol. 8, issue 2, 2016 


\begin{abstract}
From 1992, after the UN "Earth Summit" in Rio de Janeiro, sustainable development has become a priority of many countries and international organizations, including the European Union. After the crisis of 2008+ and the strong criticism of traditional economics, it also became a fundamental element of economic development in the XXI century. This new model is based on a solid and integrated economic, socio-cultural and ecological order. Such a development should be supported by suitable budgetary systems at each level of public government. The paper presents a conception of the sustainable EU own resources system and proposes the methodology of its evaluation.
\end{abstract}

Key-words

European Union own resources, sustainable development, multi-criteria statistical analysis 


\section{Introduction}

After the crisis of $2008+$, the criticism of traditional economics increased because of its impotence against social and economic problems (Stiglitz 2012; Frydman, Goldberg 2011). The economics of sustainable development model proposes an alternative path for the development of the economy in the XXI century, according to a new paradigm of integrated economic, socio-cultural and ecological order (Montaldo 2013: 1 - 4). From 1992, after the UN "Earth Summit" in Rio de Janeiro, sustainable development has become a priority of many countries and international organizations, including the European Union, as illustrated in its main documents, e.g.: the Treaty on European Union, the EU Sustainable Development Strategy 2006, and the Strategy "Europe 2020".

The sustainable development literature does not devote enough direct attention to public finance, for its primary focus is on the idea of "greening" public expenditure and tax systems. The European Union also associates sustainable development primarily with ecology and encourages Member States to green their fiscal systems. However, such an approach seems to be narrow, for the current literature does not investigate interactions between public revenues and expenditures with regard to all sustainable development objectives and the analysis does not include the EU's own resources system. Instead, a new model of the economy requires a budgetary system on each level of public finance, which supports all objectives, (ecological, economic and socio-cultural), in a balanced and integrated way, in what might be called a sustainable budgetary system.

Because of the multi-objective features, and complexity, of the system, it also requires a suitable method of assessment. Such a method should employ both qualitative and quantitative criteria of evaluation and hence provide more objectivity in the results from analysis. Previous subject literature provides rather simpler and predominantly qualitative methods of evaluation.

The paper investigates the role of the EU own resources system in achieving sustainable development objectives. The aim of the paper is to assess and compare two EU own resources systems (the binding system in the years 2000 - 2013 and the projected system for the years 2014 - 2020) according to sustainable development criteria and, if 
necessary, to propose changes towards this development. Preliminary research allows a formulation of a hypothesis that both systems supports sustainable development very poorly and needs changes.

We make our evaluation with the use of multi-criteria comparing analysis, based on the Hellwigi method consisting of a comparison of the real object with the model. The model is described by 29 detailed features (criteria of assessment) grouped into 12 positions within four main categories. In order to assess the projected system we employ the method of simulation of new resources in fiscal condition in the years $2000-2013$.

The paper has three methodological and political advantages. Firstly, it proposes a new set of assessment criteria of EU own resources, which consider new challenges in the economy. Secondly, it proposes a new method of evaluation of EU own resources. The multi-criteria statistical analysis considers both qualitative and quantitative criteria and gives an evaluation that is more objective. Thirdly, it proposes the changes in the EU own resources system that adjust it to the new sustainable challenges in the XXI century.

\section{Previous results in EU own resources assessment}

Until the end of 1980s the EU own resources system was assessed mostly with the help of simple descriptive statistics, and as such indicated general disadvantages of the system and gave proposals for its reform. In 1988 the Council obliged the Commission to prepare special regular reports on own resources. In the 1990s the Commission introduced assessment criteria for a possible new own resources framework (Commission 1992) and for binding resources (Commission 1998). Since then studies on the resources system have developed.

The subject literature formulates many different rules, principles, postulates and demands in respect of EU own resources. Some of them have become legislative norms and many of them can be also treated as assessment criteria. Figure 1 shows the sources of EU own resources criteria. 


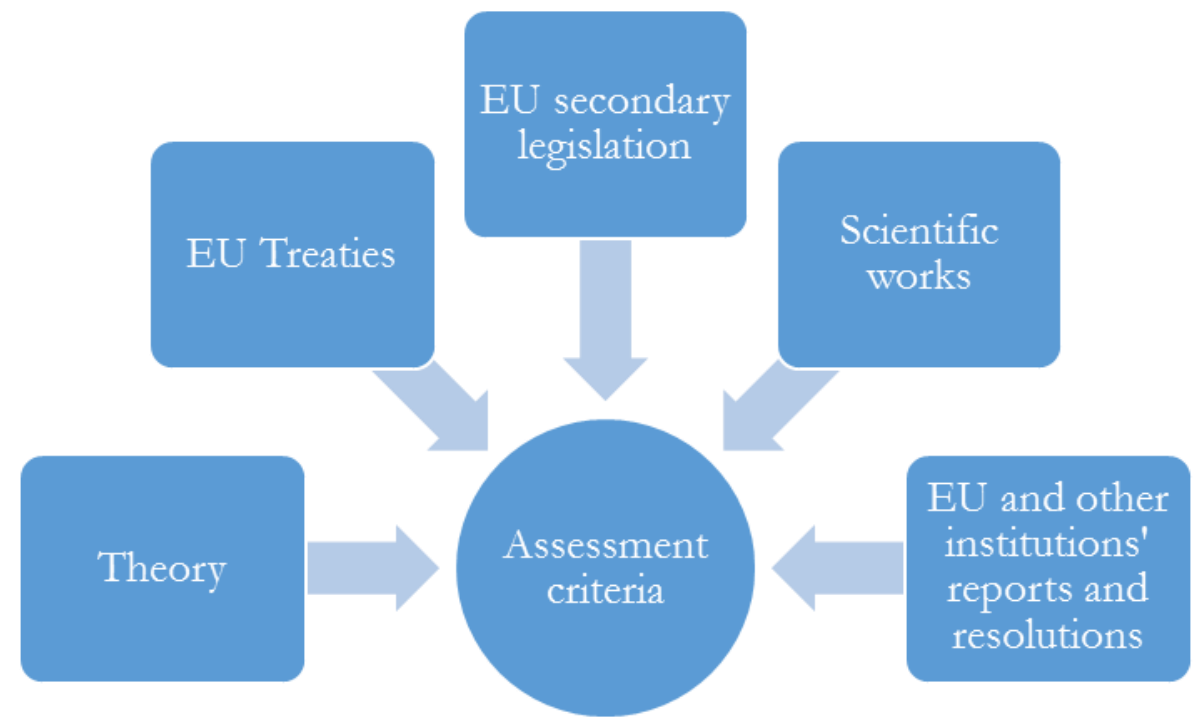

Figure 1. Sources of EU own resources criteria

Source: own study.

Theory provides an original, and the most important source of assessment criteria, and there is a wide range of theories and conceptual frameworks that can give the most relevant and useful criteria that can be used in the analysis of legislative acts, reports and other works. These include the theory of economic integration, the theory of fiscal federalism, clubs theory, tax principles, the theories of optimal taxation and optimal tax base, the conception of performance management and also more recently economics of sustainable development (Cieslukowski 2013, chapter 1; Begg, Grimwade 1998, chapter 2; Laffan 1997, chapter 2). EU Treaties present the general and fundamental principles on which European Union and Member States exist. Many principles, e.g. subsidiarity, solidarity, equity, social justice, common market, effective public finance may also determine general frameworks for EU revenues.

EU secondary legislation, mainly Council decisions on EU own resources (1970, 1985, $1988,1994,2000,2007,2014)$ and Council regulations on financial principles applicable to the EU general budget (1977 and 2002), introduces more detailed budgetary rules that create financial frames not only for the EU own resources but also for the whole budgetary system.

Scientific works fall into two groups: a) surveys conducted under contract with the Commission or European Parliament and b) research carried out by independent scientists. 
Up to 2015, the Commission had signed nine such contracts and five of them (Stable Money-Sound Finance 1993, Keen report 1995, Sapir report 2003, Begg and others report 2008 and High Level Group on Own Resources report 2014) contain criteria and evaluation on both binding and potential resources. In the same period, the European Parliament had signed only one contract for evaluation (Gretschmann report 1998).

Independent literature in English, or Polish, on EU own resources is not extensive; In the 1990s research on the criteria of binding and potential EU resources was limited to works by Spahn (1993), Begg, Grimwade (1998) and Henke (1998). From 2000 research has been carried out on the criteria by Cattoir (2004 and 2009), Cieslukowski (2005 and 2013), Alves, Cieslukowski (2006), Le Cacheux (2007) and Heinemann, Mohl, Osterloh (2008).

Important sources of the assessment criteria are also independent Commission reports (1992, 1998, 2004, 2010 and 2011), European Parliament resolutions (1994, 1999, 2007, and 2011), Court of Auditors' reports on the implementation of the budget (2005, 2006, 2007, 2008, 2009, 2010, 2011, and 2012) and House of Lords of British Parliament report (2005). The Commission usually supports the stances of the European Parliament and the Court although in some cases the criteria and methods of evaluation are debatable.

Table 1 shows the results of a meta-analysis of the most comprehensive and detailed evaluations of binding EU own resources made in the years 1998 - 2015. The following signs mean +++ (very positive), ++ (positive), + (rather positive), +- (difficult to assess, neutral), - (rather negative), - - (negative), - - - (very negative). A lack of sign means that particular research does not contain a clear assessment and empty place means that a particular criterion is not considered.

Any differences in results are mainly consequences of the author's particular views, assumptions, different periods under evaluation, and different methods of evaluations. However, the studies give quite similar results in most cases. Authors tend to agree that GNI derived resources assure fiscal efficiency and stability for the system and help to keep budgetary discipline. However, it is not consistent with EU policy and its increasing share in total revenues throws doubts on financial autonomy of the European Union. Apart from that, the system is generally cost effective, with the biggest criticism usually concerning fairness and transparency. I would stress that the Court of Auditors, the European Parliament and High Level Group on Own Resources all gave similar opinions, which 
postulate changes in the EU own resources system towards increased financial autonomy for the Union, greater solidarity between Member States, reduced complexity and improved visibility for citizens (Parliament 1994, 1999, 2007, 2011; HLGoOR 2014). In contrast, the view of the House of Lords of the British Parliament considered the system quite complex and invisible for citizens, but fair between Member States (HoL 2005).

Table 1. Results of evaluation of binding EU own resources in the years $1998-2015$

\begin{tabular}{|c|c|c|c|c|c|c|}
\hline Study & $\begin{array}{c}\text { Fiscal } \\
\text { efficiency, } \\
\text { stability and } \\
\text { discipline }\end{array}$ & $\begin{array}{l}\text { Financial } \\
\text { autonomy }\end{array}$ & Fairness & $\begin{array}{c}\text { Cost } \\
\text { effectiveness }\end{array}$ & $\begin{array}{l}\text { Simplicity } \\
\text { and } \\
\text { transparency }\end{array}$ & $\begin{array}{c}\text { Economic } \\
\text { integration } \\
\text { and market } \\
\text { effectiveness }\end{array}$ \\
\hline $\begin{array}{l}\text { Commission } \\
\text { report (1998) }\end{array}$ & $\begin{array}{l}\text { TOR }^{*}:+ \\
\text { VAT }^{* *}:++ \\
\text { GNI }^{* * *}:++\end{array}$ & $\begin{array}{l}\text { TOR: }+ \\
\text { VAT: }-- \\
\text { GNI: - - }\end{array}$ & $\begin{array}{l}\text { TOR: }- \\
\text { VAT: }++ \\
\text { GNI: }++\end{array}$ & $\begin{array}{l}\text { TOR: }--- \\
\text { VAT: }++ \\
\text { GNI: }+++\end{array}$ & $\begin{array}{l}\text { TOR: }++ \\
\text { VAT: }--- \\
\text { GNI: }+-\end{array}$ & \\
\hline $\begin{array}{l}\text { Commission } \\
\text { report (2004) }\end{array}$ & $\begin{array}{l}\text { TOR: }+ \\
\text { VAT: }+ \\
\text { GNI: }+++\end{array}$ & $\begin{array}{l}\text { TOR: }+ \\
\text { VAT: }-- \\
\text { GNI: }---\end{array}$ & $\begin{array}{l}\text { TOR: } \\
\text { VAT: } \\
\text { GNI: }+++\end{array}$ & $\begin{array}{l}\text { TOR: }--- \\
\text { VAT: }++ \\
\text { GNI: }+++\end{array}$ & $\begin{array}{l}\text { TOR: }++ \\
\text { VAT: }--- \\
\text { GNI: }+-\end{array}$ & $\begin{array}{l}\text { TOR: }+ \\
\text { VAT: }--- \\
\text { GNI: }---\end{array}$ \\
\hline $\begin{array}{l}\text { Cieslukowski } \\
(2005)\end{array}$ & $\begin{array}{l}\text { TOR: }+ \\
\text { VAT: }+ \\
\text { GNI: }+++\end{array}$ & $\begin{array}{l}\text { TOR: }+ \\
\text { VAT: }-- \\
\text { GNI: }---\end{array}$ & $\begin{array}{l}\text { TOR: }+- \\
\text { VAT: }+- \\
\text { GNI: + - }\end{array}$ & $\begin{array}{l}\text { TOR: }--- \\
\text { VAT: }++ \\
\text { GNI: }++\end{array}$ & $\begin{array}{l}\text { TOR: }+ \\
\text { VAT: }--- \\
\text { GNI: }-\end{array}$ & $\begin{array}{l}\text { TOR: }+++ \\
\text { VAT: }+++ \\
\text { GNI: }---\end{array}$ \\
\hline $\begin{array}{l}\text { Alves, } \\
\text { Cieslukowski } \\
(2006)\end{array}$ & & $\begin{array}{l}\text { TOR: }+ \\
\text { VAT: }-- \\
\text { GNI: }---\end{array}$ & & & & \\
\hline $\begin{array}{l}\text { Begg, } \\
\text { Enderlein, Le } \\
\text { Cacheux, } \\
\text { Mrak (2008) }\end{array}$ & $\begin{array}{l}\text { TOR: }+ \\
\text { VAT: }+ \\
\text { GNI: }+++\end{array}$ & $\begin{array}{l}\text { TOR: }++ \\
\text { VAT: }--- \\
\text { GNI: }---\end{array}$ & $\begin{array}{l}\text { TOR: }-- \\
\text { VAT: }+ \\
\text { GNI: }+++\end{array}$ & $\begin{array}{l}\text { TOR: }--- \\
\text { VAT: }- \\
\text { GNI: + + + }\end{array}$ & $\begin{array}{l}\text { TOR: } \\
\text { VAT: }--- \\
\text { GNI: }+++\end{array}$ & $\begin{array}{l}\text { TOR: }++ \\
\text { VAT: }--- \\
\text { GNI: }---\end{array}$ \\
\hline $\begin{array}{l}\text { Heinemann, } \\
\text { Mohl i } \\
\text { Osterloh } \\
(2008)\end{array}$ & $\begin{array}{l}\text { TOR: }+++ \\
\text { VAT: }+++ \\
\text { GNI: }+++\end{array}$ & $\begin{array}{l}\text { TOR: }+++ \\
\text { VAT: }+ \\
\text { GNI: }++\end{array}$ & $\begin{array}{l}\text { TOR: }-- \\
\text { VAT: - - } \\
\text { GNI: - - }\end{array}$ & $\begin{array}{l}\text { TOR: }--- \\
\text { VAT: }--- \\
\text { GNI: }+++\end{array}$ & $\begin{array}{l}\text { TOR: }+ \\
\text { VAT: }--- \\
\text { GNI: }+++\end{array}$ & $\begin{array}{l}\text { TOR: }-- \\
\text { VAT: - - } \\
\text { GNI: - - }\end{array}$ \\
\hline Cattoir (2009) & $\begin{array}{l}\text { TOR: }+ \\
\text { VAT: }+ \\
\text { GNI: }+++\end{array}$ & $\begin{array}{l}\text { TOR: } \\
\text { VAT: - - } \\
\text { GNI: - - }\end{array}$ & $\begin{array}{l}\text { TOR: }--- \\
\text { VAT: }--- \\
\text { GNI: }---\end{array}$ & $\begin{array}{l}\text { TOR: } \\
\text { VAT: }++ \\
\text { GNI: }++\end{array}$ & $\begin{array}{l}\text { TOR: } \\
\text { VAT: - - - } \\
\text { GNI: - - - }\end{array}$ & $\begin{array}{l}\text { TOR: }+ \\
\text { VAT: - - } \\
\text { GNI: - - }\end{array}$ \\
\hline $\begin{array}{l}\text { Commission } \\
\text { report (2011) }\end{array}$ & $\begin{array}{l}\text { TOR: }++ \\
\text { VAT: }++ \\
\text { GNI: }+++\end{array}$ & $\begin{array}{l}\text { TOR: } \\
\text { VAT: }-- \\
\text { GNI: - - }\end{array}$ & $\begin{array}{l}\text { TOR: }-- \\
\text { VAT: }-- \\
\text { GNI: - - }\end{array}$ & $\begin{array}{l}\text { TOR: }++ \\
\text { VAT: }+++ \\
\text { GNI: }+++\end{array}$ & $\begin{array}{l}\text { TOR: } \\
\text { VAT: }--- \\
\text { GNI: }---\end{array}$ & $\begin{array}{l}\text { TOR: }+ \\
\text { VAT: }-- \\
\text { GNI: }--\end{array}$ \\
\hline $\begin{array}{l}\text { Cieslukowski } \\
(2013)\end{array}$ & $\begin{array}{l}\text { TOR: }+ \\
\text { VAT: }+ \\
\text { GNI: }+++\end{array}$ & $\begin{array}{l}\text { TOR: }+++ \\
\text { VAT: }+ \\
\text { GNI: }+\end{array}$ & $\begin{array}{l}\text { TOR: }+ \\
\text { VAT: }++ \\
\text { GNI: }++\end{array}$ & $\begin{array}{l}\text { TOR: }++ \\
\text { VAT: }+++ \\
\text { GNI: }+++\end{array}$ & $\begin{array}{l}\text { TOR: }++ \\
\text { VAT: }++ \\
\text { GNI: }++\end{array}$ & $\begin{array}{l}\text { TOR: }+++ \\
\text { VAT: }++ \\
\text { GNI: }--\end{array}$ \\
\hline
\end{tabular}

Source: own study based on: Commission 1998: 5 - 8; Commission 2004, Vol. II: 8 - 13; Cieslukowski 2005: 9 - 14; Alves, Cieslukowski 2006: 4 - 8; Begg, Enderlein, Le Cacheux, Mrak 2008: 10 - 11; Cattoir 2009: 9 - 16; Commission 2011: 12 - 16; Cieslukowski 2013: 229.

*TOR - Traditional Own Resources, ${ }^{* * V A T}$ - Value Added Tax, ${ }^{* * *}$ GNI - Gross National Income

On the grounds of these studies, we propose three main directions of reform. First, a simplification of the system by replacing traditional and even VAT resources by GNI resources, second, replacing the GNI resources by new resources in order to improve 
visibility for citizens, to give financial autonomy to the European Union, and make the system more consistent with EU policy; and third, a reform of the correction mechanism to increase fairness. Table 2 shows the ranking of potential new EU own resources.

In the latest studies, resources such as FT'T, modulated VAT, European CIT and environmental taxes score relatively higher. The European Commission has, on many occasions, submitted proposals of new own resources to the Council; in its latest report from 2011 it proposed to replace GNI and VAT resources by Financial Transaction Tax and new VAT- base tax. 
Table 2. Ranking of potential new EU own resources derived from different studies (1 - first place)

\begin{tabular}{|c|c|c|c|c|c|c|c|c|c|c|}
\hline \multirow[b]{2}{*}{ Type of own resource } & \multirow{2}{*}{$\begin{array}{c}\text { European } \\
\text { Economy } \\
1993\end{array}$} & \multirow[b]{2}{*}{$\begin{array}{l}\text { Keen } \\
1995\end{array}$} & \multirow{2}{*}{$\begin{array}{c}\text { Begg, } \\
\text { Grimwade } \\
1998\end{array}$} & \multicolumn{2}{|c|}{ Gretschmann 1998} & \multirow[b]{2}{*}{$\begin{array}{l}\text { Cattoir } \\
2004 \\
2009\end{array}$} & \multirow[b]{2}{*}{$\begin{array}{l}\text { Cieslukowski } \\
2005\end{array}$} & \multirow{2}{*}{$\begin{array}{l}\text { Begg, Enderlein, } \\
\text { Le Cacheux, } \\
\text { Mrak 2008; } \\
\text { Begg 2011 }\end{array}$} & \multirow[b]{2}{*}{$\begin{array}{c}\text { Commission } \\
2011\end{array}$} & \multirow[b]{2}{*}{$\begin{array}{c}\text { Cieslukowski } \\
2013\end{array}$} \\
\hline & & & & $\begin{array}{c}\text { Quantitative } \\
\text { analysis }\end{array}$ & $\begin{array}{l}\text { Qualitative } \\
\text { analysis }\end{array}$ & & & & & \\
\hline PIT & 5 & 5 & 5 & 6 & 7 & 2 & 5 & 6 & & \\
\hline European CIT & 2 i3 & 3 i 4 & 4 & 1 & 1 & 5 & 6 & $1 \mathrm{i} 2$ & - & \\
\hline Withholding Tax & 4 & 2 & 7 & 7 & 4 & & 3 & - & & \\
\hline $\begin{array}{l}\text { Financial Transaction } \\
\text { Tax (FTT) }\end{array}$ & & & & & & 7 & & $5^{* *}$ & + & 1 \\
\hline $\begin{array}{l}\text { Financial Assets Tax } \\
\text { (FAT) }\end{array}$ & & & & & & & & & + & \\
\hline Modulated VAT & 3 & 1 & 1 & 8 & 5 & 3 & 1 & 3 & + & 2 \\
\hline Communication Taxes & - & - & 2 & 5 & 8 & 5 & 4 & 3 & & \\
\hline $\begin{array}{l}\text { Environmental } \\
\text { Tax/Energy Tax }\end{array}$ & 1 & 2 & 6 & 2 & 6 & $1,4^{*}$ & 2 & $1 *, 2^{* * *}, 7^{* * * *}$ & $-,-*,-* * * * *$ & \\
\hline $\begin{array}{l}\text { Excises on Alcohol and } \\
\text { Tobacco Products }\end{array}$ & 4 & 4 & 3 & 4 & 3 & 6 & 7 & & & \\
\hline Wealth Tax & 5 & & & & & & & & & \\
\hline Seigniorage Revenues & 2 & 3 & 8 & 3 & 2 & 5 & 8 & 4 & & \\
\hline
\end{tabular}

Source: own study based on: European Economy 1993: 85; Keen 1995: 81; Begg, Grimwade 1998: 146; Gretschmann 1998: 108; Cattoir 2004: 15 - 37; Cieslukowski 2005: 18 and 19; Begg, Enderlein, Le Cacheux, Mrak 2008: 95 - 97; Begg 2011: 15 - 17; Commission 2011; Cieslukowski $2013: 268$.

* airplane charge on $\mathrm{CO}_{2}$ emission; ** no numerical assessment of fiscal efficiency and stability but it seems to have huge fiscal potential, *** petrol charge; **** revenues from the trade of $\mathrm{CO}_{2}$ emission.

+ possible to introduce, - impossible to introduce 
However, Members States did not reach a final agreement and the core of the system, apart from small corrections, remained unchanged for the years 2014 - 2020. Instead, Member States promised to continue discussion and some of them (Italy, Portugal and Spain) decided to introduce FTT in their tax systems in the near future. In February 2016, Poland also introduced a new tax on assets of some financial institutions.

Previous studies on the EU characterize own resources by the following features:

1) In Commission reports in particular the link between criteria and theory is very loose,

2) The number of criteria used in evaluations is small with the focus on fairness between Member States. Additionally, there are more qualitative criteria than quantitative ones. Consequently, results of evaluations have become less objective and more open to discussion. Current statistical methods give possibilities to conduct more objective evaluations,

3) Criteria are not weighted. Weighting improves credibility and objectiveness of evaluation,

4) Most current studies (particularly Commission reports) evaluate the whole system from the angle of some "explosive" criteria. They do not analyze the system in detail and do not give an objective assessment of the whole system,

5) In most cases resources are evaluated over short periods of time which creates difficulties in drawing reliable conclusions about changes in the quality of the whole system over a longer period of time,

6) The evaluations do not compare particular resources,

7) The evaluations do not consider sustainable development objectives in integrated and balanced ways.

Studies on EU own resources need further improving towards obtaining more objective and convincing results. Analysis should consider:

1) A better link between theory and criteria,

2) The use of a larger number of detailed, weighted, qualitative and quantitative criteria,

3) The employment of multi-criteria analysis that allows the integration of different criteria, comparison of resources, to produce more objective results 
4) An evaluation of the whole system over a longer period of time,

5) Evaluation should employ sustainable development criteria.

\section{The role of public revenues in sustainable development}

Analysis of sustainable development takes place across different scientific disciplines, economy sectors and all public government levels. However, the subject literature does not direct particular attention to public finance and public revenues; their focus is on ecological taxes and "greening" tax systems (Rogall 2010: 280 - 287; Koglin 2009: 11; Environment Group 2006: 89 - 93; Wallart 1999: 138). Sustainable development economists willingly promote these taxes not only for their ecological advantages but also for the assumption of additional positive influences on the economy, the work place, innovation, the social security system and even on world peace.

States both developed and developing, e.g. China and Turkey, have already conducted "green" reforms (OECD 2001: 49 - 55). However, the results of the reforms turn out to be different depending on the models of evaluation employed (general or partial equilibrium), and assumptions made (types of taxes, period, dependent variables, directions of expenditures etc.). The subject literature is extensive, but a comprehensive overview is given by the research of Hoerner and Bosquet (2001); this contains a meta-analysis of 104 simulations of the results of "green" tax reforms conducted by ten EU developed Member States in the 1990s, from which we derive four conclusions. Firstly, $78 \%$ of simulations predict an increase in employment, although a more effective way is the reduction of obligatory social contributions rather than a reduction of income taxes. Secondly, $75 \%$ of simulations predict little influence on GDP (from - 0,5 do $+0,5 \%$ ). Thirdly, ecological taxes should replace obligatory social contributions since reductions of VAT and income taxes give moderate results. Finally, most simulations predict an increase in prices and decrease in investments.

Another study by Bosquet (2000: 23 - 28) shows that eco-taxes may have an adverse impact on companies that have huge demands for energy. Some simulations carried out in Poland also confirm these conclusions, notably a study on Coal Tax in 2001 by the Institute for Eco-development (Stodulski (ed.) 2001). Simulations made for the years 1995 - 2005 with the help of the general equilibrium model, and for six scenarios, assumed a 
different scope for reform. Simulations confirm a positive influence on reduction of $\mathrm{CO}_{2}$ emission and on economic growth and employment; however, this was only valid under a condition of a reduction on labour costs. Conversely, the research does not confirm any negative influence on prices and energy-intensive sectors.

Apart from "greening", proponents of economics of sustainable development also propose other changes in taxes; however, these need further theoretical and empirical verification. The recommendations are as follows (Rogall 2010: 339; Felber 2015: 89 - 90]: imposing taxes on financial transactions, increasing the top PIT and basic VAT rates, elimination of tax havens, introduction of high penalties for tax avoidance, stimulation of sustainable behavior by tax reliefs and preferences, and employing appropriate inheritance $\operatorname{tax}$

Sustainable development economists also claim that the new model needs global management. They suggest either creating a new international organization, or equipping existing international organizations (e.g. United Nations) with additional and efficient fiscal resources, such as: a tax on financial transactions, penalty customs duties for failing in meeting ecological standards, and contributions for consumption of global sources (e.g. air space, oceans).

Sustainable development has also become the priority for the European Union, as illustrated in its main documents: The Treaty on European Union (Treaty 2012: art. 3), The EU Sustainable Development Strategy 2006 (Council 2006) and The "Europe 2020" Strategy (Strategy 2020: 11). However, the objective is mainly achieved through budgetary expenditures. All beneficiaries of EU subsidies are obliged to evaluate their projects with regard to sustainable development criteria. In respect of revenues, until now the European Union influenced sustainable development in a rather indirect manner. It mainly encourages the Member States to "green" their tax systems (Council 2006: 24). Additionally it harmonized the taxation of energy in 2003 (Commission 2003) and is still consider introducing a solidarity contribution on air tickets (Commission 2005).

\section{Conception and assessment criteria of the sustainable European Union own resources system}

The subject literature also proposes conceptions of the sustainable tax and tax system 
and criteria of their assessment (Cieslukowski 2014). However, with regard to the present European Union's stage of political and economic development, their employment is impossible; they need modifying in the context of the current specificity of the European Union.

The sustainable EU own resource is a resource that contributes to sustainable development, and, as such, it should meet all fundamental criteria: (ecological, economic, and socio-cultural) as well as administrative criteria. ${ }^{\text {II }}$ It is possible to create a typology of these resources with regard to their degree of meeting the criteria: (strongly) sustainable, sustainable moderately, sustainable poorly, neutral, unsustainable poorly, unsustainable moderately and unsustainable (table 3).

Table 3. Types of EU own resources with regard to the degree of sustainability

\begin{tabular}{|l|c|c|c|c|}
\hline \multirow{2}{*}{ Type of a tax } & \multicolumn{4}{|c|}{ Objectives } \\
\cline { 2 - 5 } & Ecological & Economic & Socio-cultural & Administrative \\
\hline Sustainable & + & + & + & + \\
\hline \multirow{2}{*}{ Sustainable } & + & + & 0 & + \\
moderately & + & 0 & + & + \\
\hline Sustainable & 0 & + & 0 & + \\
poorly & + & + & 0 & + \\
\hline Neutral & 0 & 0 & 0 & + \\
\hline Unsustainable & 0 & 0 & $0+$ & + \\
poorly & - & $0+$ & $0+$ & + \\
\hline Unsustainable & - & - & - & + \\
moderately & - & - & & + \\
\hline Unsustainable & - & & & \\
\hline
\end{tabular}

Source: own study.

+ positive; - negative, 0 neutral

A moderate resource meets at least two fundamental criteria and administrative criteria and a poor resource meets only one group of fundamental criteria and administrative criteria. A neutral resource does not affect the sustainable development nor in a positive or negative way and an unsustainable resource affects in a negative way at least one type of criteria.

We define the sustainable EU own resources system as a system of logically connected resources that as a whole contributes to sustainable development. Such a system can only be composed of resources categorized as sustainable and neutral. Apart from the sustainable system, we can identify neutral and unsustainable systems, where the former 
has no effect on sustainable development and the latter, dominated by unsustainable resources, affects sustainable development negatively. We can also develop a framework for categorizing resources in the same way that we did for the debate on systems, although this is more of a challenge. Table 4 contains the proposals of such criteria, drawn from the theory and sources presented in point 1 of the paper, and recommendations of sustainable development economics.

Table 4. Assessment criteria of EU own resources sustainability

\begin{tabular}{|l|l|l|l|}
\hline \multicolumn{1}{|c|}{$\begin{array}{c}\text { Ecological } \\
\text { criteria }\end{array}$} & \multicolumn{1}{|c|}{$\begin{array}{c}\text { Economic } \\
\text { criteria }\end{array}$} & \multicolumn{1}{c|}{$\begin{array}{c}\text { Socio-cultural } \\
\text { criteria }\end{array}$} & $\begin{array}{c}\text { Administrative } \\
\text { criteria }\end{array}$ \\
\hline $\begin{array}{l}\text { Sustainable exploitation } \\
\text { of natural resources }\end{array}$ & $\begin{array}{l}\text { Fiscal efficiency and } \\
\text { stability }\end{array}$ & Democratic accountability & Cost effectiveness \\
\hline Healthy life conditions & $\begin{array}{l}\text { Fairness between } \\
\text { Member States }\end{array}$ & $\begin{array}{l}\text { Fiscal sovereignty of the } \\
\text { Member States }\end{array}$ & Transparency \\
\hline $\begin{array}{l}\text { Pro-ecological behavior } \\
\text { of consumers and } \\
\text { companies }\end{array}$ & $\begin{array}{l}\text { Economic } \\
\text { integration }\end{array}$ & $\begin{array}{l}\text { Financial autonomy of the } \\
\text { European Union }\end{array}$ & Sustainable statistics \\
\hline
\end{tabular}

The first rubric, Ecological criteria, is qualitative, and divided into three criteria. The role of public revenues in sustainable exploitation of natural resources generally comes down to the internalization of the ecological costs. It consists of employing special ecological taxes and fees, which increase the prices of particular goods and services, and through this, the consumer should rationalize their consumption and exploitation. Healthy living conditions are improved by the elimination of harmful substances, noise, radiation, air pollution etc. Special taxes, fees and financial penalties can be imposed on different institutions and companies in order to prevent such activity. Public resources can also be used to encourage companies and citizens to pro-ecological behavior, mainly in order to maintain the species and landscape diversity. Such instruments as additional taxes, fees and penalties can limit negative impact on environment but on the other hand, such instruments as special tax allowances and preferences can be used to encourage companies and citizens to ecological investments and leading ecological style of life. For all the above we limit our assessment to legal solutions on EU own resources with regard to their influence. 
The second rubric includes economic criteria [based on quantitative data]. Fiscal efficiency of the resource means its capability to reinforce the EU budget with revenues in particular periods of time, and its inherent fiscal discipline (in the years $2000-2013$ own resources cannot exceed 1,24\% of EU GNI and the EU budget must be balanced). The optimal solution is where a few fiscally similar resources reinforce the EU's general budget (Cieslukowski, 2013: 165). We measure fiscal efficiency by the share of the resource in the EU's total revenues, according to the formula:

$$
F E I_{r_{t}}=\frac{r_{t}}{\sum \operatorname{Tr}_{t}}-\frac{1}{l_{t}}
$$

where: $F E I_{r_{t}}$ fiscal efficiency indicator for the particular resource $r$ in the period $t, r{ }_{-}$ revenues from the particular resource in period $t, \sum T r_{t}$ - total EU budget revenues in the period $t, l_{t}-$ a number of EU own resources in period $t$. In the years $2000-2008$ an optimal share of a particular resource in total revenues is $16.67 \%$ and in the following years $-20 \% .{ }^{\mathrm{III}}$ For each year, five different brackets of efficiency are set, showing the difference between optimal and real shares.

Stability of the resource means its resistance to fluctuations caused by internal and external factors; we measure stability with a fiscal stability indicator according to the formula:

$$
F S I_{r_{t}}=\frac{S_{y}}{\bar{X}} \cdot 100,(3.2)
$$

where: $F S I_{r_{t}}$ fiscal stability indicator of the particular resource in period $t,{ }^{S_{y}}-$ a standard statistical error of the regression function for particular series of revenues $(Y)$ in period $t, \bar{X}$ - an arithmetic average for particular series of revenues $(Y)$ in period $t$. Statistics assumes that the phenomena is stable when the indicator is lower than $20 \%$. In the paper, five brackets of stability are set: $[0-10 \%$ ) (very stable); [10 - 20\%) (stable); [20 - 30\%) (moderately stable); [30 - 40\%) (unstable) and over 40\% (very unstable).

Usually we would see to analyse the fairness of the fiscal burden both between EU Member States and between their citizens. However the current and proposed EU own resources systems do not impose taxes directly on citizens, so analysis of fairness in the 
second case seems to be pointless. Fairness between Member States, according to the Treaty on European Union (protocol 28), exists when the fiscal burden on Member States is proportional to their share of EU GNI. We evaluate fairness with the help of the Pearson Concentration Coefficient $(\mathrm{K})$. In the paper ten brackets of concentration are set: $[0,0-0,2]$ (very fair breakdown), [0,2 - 0,4] (fair breakdown), [0,4 - 0,6] (moderate breakdown), $[0,6-0,8]$ (unfair breakdown) and over [0,8 - 1,0] (very unfair breakdown).

We draw economic integration criteria from economic integration and fiscal federalism theories, which also express the Treaty rule of subsidiarity. We define three detailed criteria: 1) an even breakdown of revenue bases between Member States, 2) tackling negative external effects and 3) tackling accidental division of public revenues between Member States.

We treat revenue bases in a broad perspective: for customs duties, it is the value of imports; for sugar fees, the size of sugar production in tons; for VAT resources, the value of consumption; and for GNI resources, the value of GNI. Once again, we used the Pearson Concentration Coefficient $(\mathrm{K})$ to determine the breakdown of the bases between Member States, using the same brackets as above.

Criteria of tackling negative external effects and accidental division of revenues are rather qualitative. However, in the paper we assume that the resources perfectly meet the criteria if they reinforce the EU budget completely. Then we employ the Resource Property Indicator according to the formula:

$$
R P I_{r_{t}}=\frac{r_{t}}{T r_{t}} \cdot 100,(3.3)
$$

where $R P I_{r_{t}}$ - resource property indicator in period $t,{ }^{r}-$ EU revenues from a particular resource in period $t, T r_{t}$ - Total revenues from a particular resource in period $t$. We employ the following brackets of EU resource property: [zero- 20\%] (state resource), [20 - 40\%] (divided state resource), [41 - 60\%] (moderate divided resource), [60-80\%] (divided EU resource), and [80-100\%] (EU resource).

In the third rubric, we develop the socio-economic criteria. Democratic accountability is a qualitative criterion and with regard to the EU's own resources assesses the influence that citizens have on resources. Such influence can only exist with the help of the European Parliament, which should have real legislative power over resources. 
Fiscal sovereignty of the Member States is also a qualitative criterion and means that the EU resources cannot be deployed without respect for national independence and interest; in other words, all Member States should reach agreement in the case of the resource.

The European Union has a degree of financial autonomy when it possesses real own resources. According to the theory, a real resource should meet the following conditions: 1) it is situated on EU territory; 2) it belongs to the EU entirely and permanently; 3) it is directly imposed on taxpayers; and 4) the EU decides on its construction (Alves, Cieslukowski, 2006: 3 - 4). Most of the criteria are qualitative, only completeness is quantitative and we assess this with the help of the Resource Property Indicator (3.3).

The costs of collecting EU revenues should be as lowest as possible for the European Union, Member States and "tax payers". Our assessment of the scale of resource costs for the European Union and Member States is based on the relation of costs to collected revenues, according to the formula:

$$
C I_{r_{t}}=\frac{c_{r_{t}}}{T r_{t}} \cdot 100,(3.4)
$$

where $C I_{r_{t}}$ - cost indicator of particular resource $r$ in period $t,{ }^{c}{ }_{r_{t}}$ - collecting costs of particular resource $r$ in period $t, T r_{t}-$ EU revenues from particular resource $r$ in period $t$. Five brackets of cost effectiveness are employed: [zero - 1,0\%] (very low costs), [1,0\% $2,0 \%]$ (low costs), $[2,0 \%-3,0 \%]$ (moderate costs), $[3,0 \%-4,0 \%]$ (high costs) and over $4,0 \%$ (very high costs).

The EU costs comprise those of legislation, revenue management, control, audit and advisory. Such costs are paid by the EU Council, European Parliament, European Commission (General Budgetary Directory), OLAF, Court of Auditors, Internal Audit Service (IAS) and Committee of Socio-economic Affairs (CSEA). The costs of the EU Council linked to particular resources are assessed on the number of legislation pages dedicated to the revenues and total costs of functioning. The costs of the European Commission are assessed on the base of employment structure in particular revenue departments and total costs of functioning. The costs of the Court of Auditors are assessed on the base of the number of pages dedicated to the particular revenues in all issued documents (annual operating reports, annual financial reports, detailed reports and 
opinions) and total costs of functioning. The costs of OLAF are assessed on the base of the number of the proceedings and total costs of functioning. The costs of IAS are assessed on the base of the number of audits in General Budgetary Directory and the total cost of functioning. The costs of the CSEA are assessed on the base of the number of opinions dedicated to EU resources and the total costs of functioning. Finally, the costs of the Parliament are assessed based on the number of issued law acts with the EU Council (Customs Code), separate opinions, the costs of expert evaluations dedicated to the EU resources and the total costs of functioning.

We evaluate the costs of the Member States on the basis of the costs of the tax and customs duties administration. The sources of information are two OECD documents from 2004, and 2011, comparing the tax administration in OECD countries: Tax Administration in OECD Countries: Comparative Information Series 2004 [OECD 2004, p. 65] and Tax Administration in OECD and Selected Non-OECD Countries: Comparative Information Series (2010) (OECD 2011: 126 and 127). Such a way of costs assessment seems to be suitable in the case of customs duties, sugar fees and VAT resource because Member States are responsible for administering the collection and transfer of revenues to the EU budget.

In the case of GNI resources the role of Member State comes down mainly to the calculation and transferring of due payments according to the EU's schedule. Then the costs of Member States are rather marginal and they are assumed at the level of $0.1 \%$ of transferred amounts.

We measure costs for "tax payers" with the help of two indicators. We derive the costs of VAT and sugar fees by taking the average number of hours necessary to calculate and pay taxes in particular Member States. Five time brackets are set in each year of analysis. We calculate costs of customs duties by the number of obligatory documents necessary during customs clearance procedure in particular Member States. We source our data from two reports: Paying Taxes. The global Picture from the years 2006 - 2012, issued by PricewaterhouseCoopers and World Bank; and Doing Business from the years 2006 - 2012 issued by the World Bank and International Monetary Fund. In the case of sugar fees, we make our assessment using the example of Polish organizational solutions.

Transparent resources means that EU citizens know how much and why they pay for $\mathrm{EU}$, who decides about the resources and if the resources are managed professionally. We define transparency using a number of detailed qualitative and quantitative criteria: 1) 
openness, 2) public consultations, 3) number of law acts, 4) independent control and audit, 5) transparency of construction, 6) accessibility in a mother language, 7) high accountability standards, 8) essential grounds for the revenues and 9) performance management. On the further analysis, we find that only the third criterion is quantitative, and we set five brackets of assessment for each year according to the number of law acts.

Sustainable statistics, a qualitative criterion, present new models of calculating our prosperity and wealth. Such indicators as GDP or GNI are currently strongly criticized because they are strictly monetary measures, and do not take into consideration many important variables that concern the quality of life, e.g. the quality of the natural environment, the quality of health and education, and happiness. The subject literature proposes some new indicators (New Zeeland Composite Sustainable Development Index, Ecological Footprint, Environmental Sustainable Index etc.), which express better sustainable development (Lawn (ed.) 2006). New indicators should also be used in European statistics, including calculations connected with EU own resources.

\section{The Methodology of evaluation}

We evaluate the data through a compilation of two linear classification methods: 1) a benchmarking method; and 2) a scoring method. Hellwig originally presented the benchmarking method in 1968, and at the core is a hypothetical model to which the evaluated object is compared, using special measures to calculate the distance between the model and the object. The scoring method evaluates the object's features (weighted and normalized variables) with regard to the criteria with the help of a special system of points.

The evaluation procedure of one object (the particular resource or the whole system) consists of the following steps:

1) Preparing the benchmarking positive model,

2) Weighting the criteria,

3) Calculation of the weighted value of the model,

4) Evaluation of the object with regard to the criteria with the help of the scoring method,

5) Comparing the object with the model (calculation of the taxonomic measure that indicates the stage of development of the object in comparison to the model), 
6) Graphic presentation of the results and interpretation.

The benchmarking model consists of qualitative and quantitative criteria, to which we compare the evaluated object. With regard to the limits of information the model has only a positive character (is a stimulant) which means that high values of variables are preferable to low values. We select our variables (criteria) with the help of the heuristic method and they meet statistical essential and formal features. We present the main categories of criteria in table 4; in total, we employ 29 detailed criteria, grouped into 12 positions within four main categories.

All four categories of criteria have the same weighting (0.25), and are normalized. Equality between the criteria arises due to the sustainability of the system. The total weighted value of the model $\left(A_{w}\right)$ equals the sum of the weighted variables $\left(V_{m j}\right)$ :

$$
A_{w}=\sum_{j=1}^{n} V_{w j}
$$

where: $V_{w j}=w_{j} \cdot q_{w j}, V_{w j}$ - value of the weighted model with regard to the criterion $j, w_{j}-$ weighting of criterion $j, q_{w j}$ - maximum value of the assessment with regard to the criterion $j$ $\mathrm{y}, w$ - benchmarking object, $j=1, \ldots, \mathrm{n}$ - assessment criteria. We express the maximum value of the assessment $\left(q_{w j}\right)$, dependent on the criterion, in a special point scale or indicator (e.g. quotient).

The evaluation of the object is the measurement of the degree to which the particular weighted criterion is met by the particular object, and is expressed by the following formula:

$$
V_{i j}=w_{j} \cdot q_{i j},(4.2)
$$

where: $V_{i j}$ - weighted value of criterion $i$ of the object with regard to assessment criterion $j$, $w_{j}$ - weighting of assessment criterion $j, q_{i j}$ - evaluation of the object $i$ with regard to the assessment criterion $j, i=1, \ldots, \mathrm{m}-$ objects of the evaluation, $j=1, \ldots, \mathrm{n}-$ assessment criteria.

Evaluation of the object $\left(q_{i j}\right)$ can be expressed in a special point scale or indicator (e.g. quotient). The final aggregated total value of the object $\left(A_{i}\right)$ is the sum of weighted values of particular variables $\left(V_{i j}\right)$ : 


$$
A_{i}=\sum_{j=1}^{n} V_{i j}
$$

We can calculate the distance between the model and the evaluated object a number of measures. Usually different measures are employed for quantitative (e.g. Euclidean, urban, Bray and Curtis, Jeffreys and Matusito, "Canberra") and qualitative (e.g. Russel-Rao, Jaccard, Dice'a, Sokal-Michener) variables. Here, both types of criteria describe the EU own resources system, so firstly the special procedure of transforming variables into one quantitative category is employed (by the scoring method). We evaluate Evaluation of each resource with regard to the particular criterion with the help of the following uniform scoring scale:10 pt. - meets criterion very well, 8 pt. - well, 6 pt. -moderately, 4 pt. poorly, 2 pt. - very poorly and 0 pt. - does not meet the criterion at all or is neutral.

Next, we calculate the distance between the model and the evaluated object with the help of normalization and Euclidean distance:

$$
d_{i w}=\sqrt{\sum_{j=1}^{n}\left(V_{i j}-V_{w j}\right)^{2}},
$$

where $d_{i w}$ - Euclidean distance between the model $w$ and the object $i, V_{i j}$ - weighted value of the object with regard to the $j$ criterion, $V_{m j}$ - weighted value of the model with regard to the $j$ criterion. The distance is smaller the object is closer the model.

Finally, each object is described by a taxonomic measure $\left(m_{i}\right)$ that indicates the stage of its development, according to the formula:

$$
m_{i}=1-\frac{d_{i w}}{d_{w}}
$$

where

$$
d_{w}=\sqrt{\sum_{j=1}^{n}\left(V_{w j}-V_{-w j}\right)^{2}}
$$

and $d_{w}$ is the Euclidean distance between the positive and negative model with regard to the criterion $j$ and $V_{-w j}$ - weighted value of the negative model with regard to the criterion $j$. The assessment value comprises the range [0-1], $m_{i}=0$ for the negative model and $m_{i}=1$ for the positive. The higher the value of $m_{i}$, the closer the object is to the model. However, the analysis comprises only positive models, so the distance $d_{w}=1$ and finally:

$$
m_{i}=1-d_{i w} .(4.7)
$$


The paper presents analysis for both systems (binding and projected) in three dimensions: 1) an assessment of the whole system with regard to all criteria, 2) an assessment of the whole system with regard to 12 criteria and 3) an assessment of particular resources with regard to all criteria. Additionally we assess the binding resources according to four main categories of criteria and compare the projected resources with the binding ones. Depending on the dimension analysis and results, we assess the sustainability rate $m_{i}$ according to a different scoring scale. It means that the rates $m_{i}$ result in different dimensions and cannot be compared to each other because they use different bases in distance calculation. The general rule is that the nearer $m_{i}$ is to 1 , the more the system (resource) is sustainable. We present our results in radar and bar graphs.

\section{Results of the evaluations}

6.1. The EU own resources system in the years $2000-2013$

Between 2000-2006, and 2007-2013, two financial perspectives were applied and there were changes to EU own resources; in Table 5 we present the main features of the system in these periods.

The taxonomic rate of development for the whole EU own resources system $\left(m_{2000}\right.$ ${ }_{2013}$ is assessed at the level of 0,331 in the scale $[0,0 ; 1,0]$. It means that the system is generally poor but acceptable.

Analysis according to the main 12 criteria shows an unequal development of the system. Graph 1 shows that the system mainly supports fiscal sovereignty of the Member States, assures European Union fiscal autonomy and is cost effective. Additionally the system supports economic integration quiet well. On the other hand, the resources do not support natural environment protection or they are neutral with regard to this challenge. 
Table 5. Construction of the EU own resources in the years 2000 - 2013

\begin{tabular}{|c|c|c|}
\hline Category & $2000-2006$ & $2007-2013$ \\
\hline $\begin{array}{l}\text { Types of } \\
\text { resources }\end{array}$ & $\begin{array}{l}\text { Agricultural duties, sugar fees, } \\
\text { customs duties, VAT, GNI (GNP in } \\
2000 \text { and 2001) }\end{array}$ & $\begin{array}{l}\text { Agricultural duties (until 2008), sugar } \\
\text { fees, customs duties, VAT, GNI }\end{array}$ \\
\hline $\begin{array}{l}\text { Customs } \\
\text { duties and } \\
\text { sugar fees }\end{array}$ & $\begin{array}{l}\text { Collection costs } 10 \text { and } 25 \% \text { (since } \\
2001 \text { ), } \\
\text { Different collection rules for } \\
\text { customs and agricultural duties }\end{array}$ & $\begin{array}{l}\text { Collection costs } 25 \% \text {, } \\
\text { Common Customs Tariffs for } \\
\text { agricultural and customs duties }\end{array}$ \\
\hline VAT & $\begin{array}{l}\text { Base limitation to } 50 \% \text { of GNI } \\
\text { (GNP in } 2000 \text { and 2001), } \\
\text { Uniform rate (difference between } \\
\text { Maxima rate and ,frozen” rate) }\end{array}$ & $\begin{array}{l}\text { Base limitation to } 50 \% \text { of GNI, } \\
\text { Uniform rate } 0,30 \% \text {, } \\
\text { Reduced rates for: Austria } 0,225 \% \text {, } \\
\text { Germany }-0,15 \% \text {, Netherlands and } \\
\text { Sweden }-0,10 \%\end{array}$ \\
\hline GNI & $\begin{array}{l}\text { Base calculated in market prices, } \\
\text { ESA } 95 \text { (GNI) (ESA } 79 \text { (GNP) in } \\
2000 \text { and 2001, } \\
\text { Uniform rate calculated during the } \\
\text { budgetary procedure }\end{array}$ & $\begin{array}{l}\text { Base calculated in market prices, ESA } 95 \\
\text { (GNI), } \\
\text { Uniform rate calculated during the } \\
\text { budgetary procedure, } \\
\text { Yearly relief amount for Netherlands } \\
(€ 605 \mathrm{~m}) \text { and Sweden (€150m) in } 2004 \\
\text { prices }\end{array}$ \\
\hline Corrections & $\begin{array}{l}\text { Rabate for UK, } \\
\text { Relief in financing UK rebate for } \\
\text { Germany }-2 / 3 \text { original amount in } \\
\text { the years } 2000 \text { and } 2001 \\
\text { Reliefs in financing UK rebate for } \\
\text { Austria, Germany, Netherlands and } \\
\text { Sweden - } 1 / 4 \text { original amount since } \\
2002\end{array}$ & $\begin{array}{l}\text { Some changes in UK rebate since } 2009 \text {, } \\
\text { Reliefs in financing UK rebate for } \\
\text { Austria, Germany, Netherlands and } \\
\text { Sweden - } 1 / 4 \text { original amount }\end{array}$ \\
\hline Limits & $\begin{array}{l}\text { For payments: } 1,27 \% \text { of GNP in the } \\
\text { years } 2000-2002,1,24 \% \text { of GNI } \\
\text { Since } 2003 \text {, } \\
\text { For commitments: } 1,335 \% \text { of GNP } \\
\text { in the years } 2000-2002,1,31 \% \text { of } \\
\text { GNI since } 2003\end{array}$ & $\begin{array}{l}1,24 \% \text { of GNI for payments and } 1,31 \% \\
\text { GNI for commitments }\end{array}$ \\
\hline
\end{tabular}

Source: own study based on Council (2000) and (2007). 


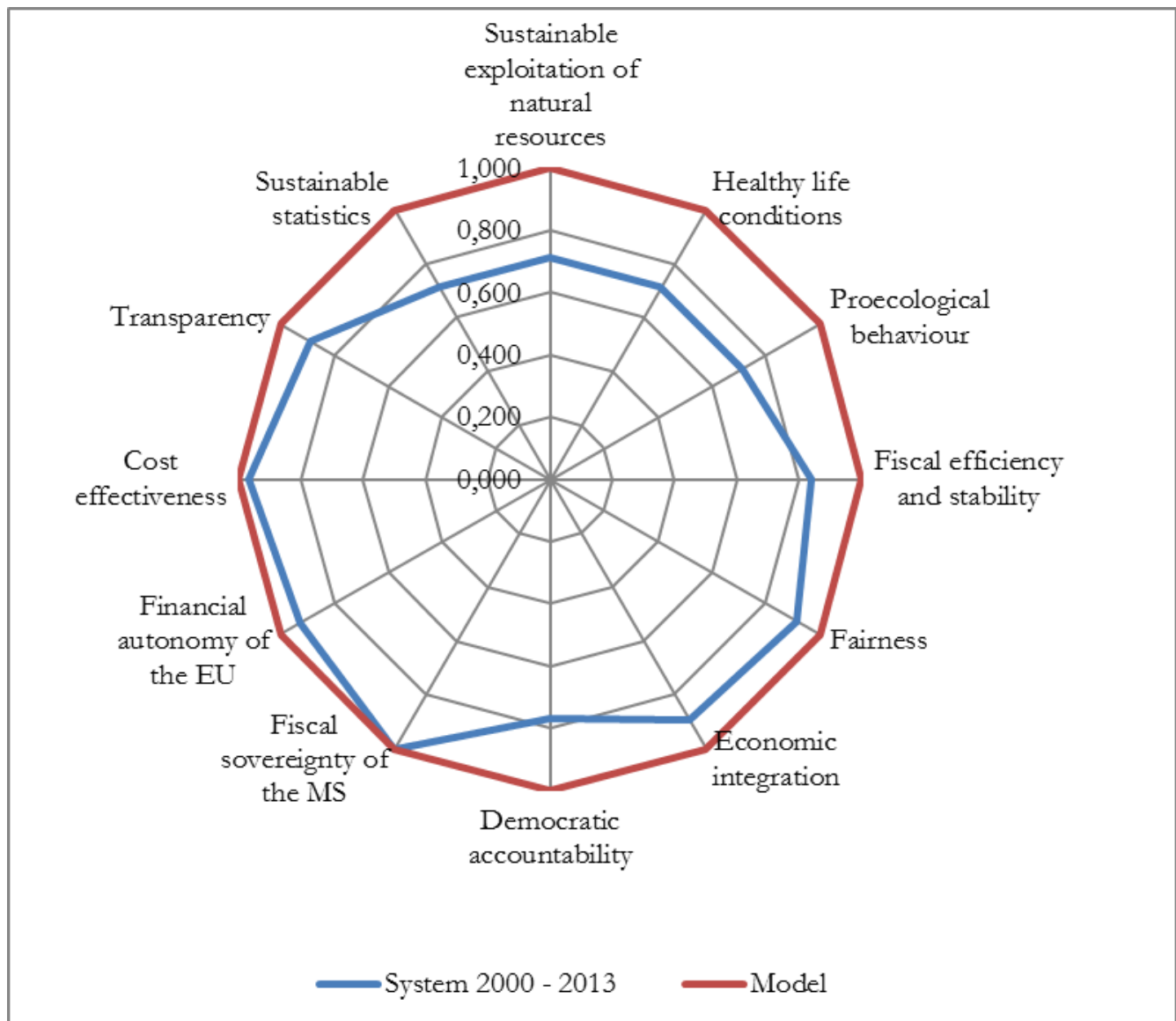

Graph 1. The EU resources system according to the main categories of criteria Source: own calculations.

We assessed particular resources at a similar level to the whole system (graph 2), from which we can generalize that all resources support sustainable development poorly. Customs and agricultural duties attained the highest level whereas GNI received the poorest score in our assessments. 


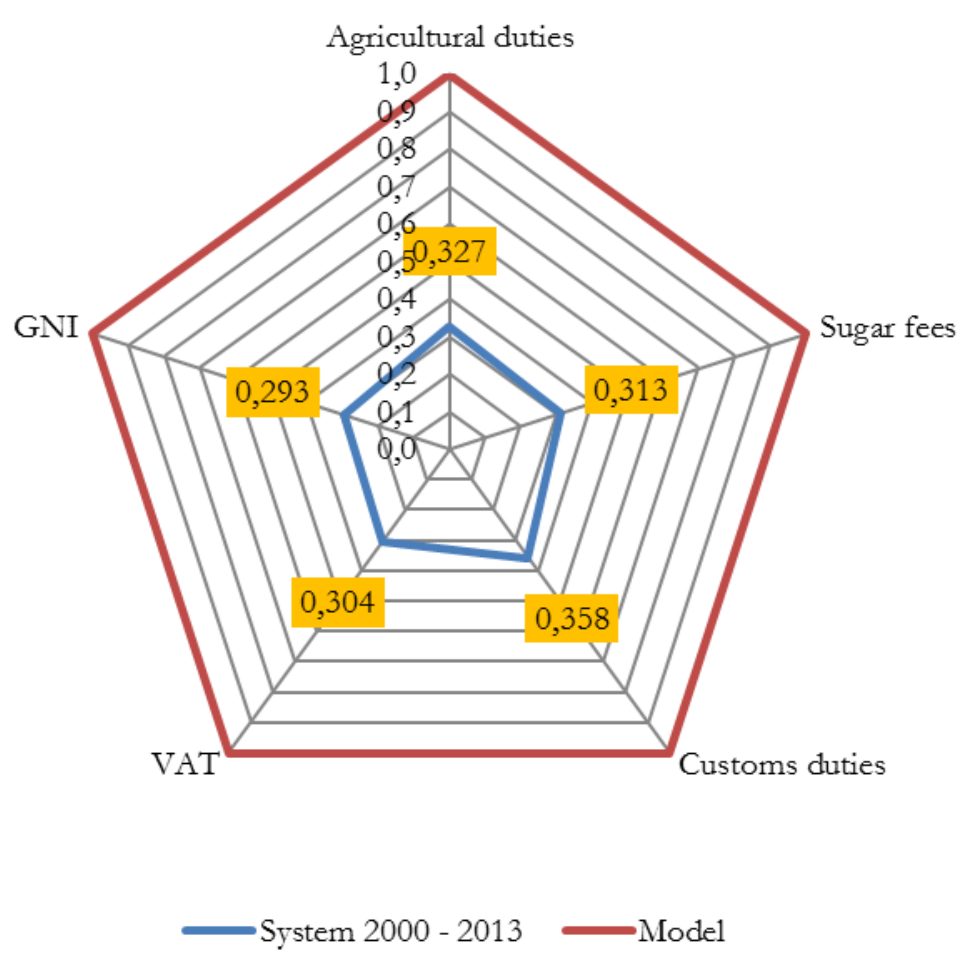

Graph 2. Taxonomic rates of EU own resources development in the years $2000-$ 2013

Source: own calculations.

Graph 3 shows relations between the resources with regard to the main four categories of criteria. It shows a generally equal development of resources except for the influence on ecology. Resources mainly support economic and socio-cultural development and are acceptable with regard to the administrative criteria. In particular, our assessment shows that customs score highly as quite good tools of economic integration, fiscal efficiency and stability. On the other hand, legal acts that regulate resources do not, in the main, include clear rules supporting ecological development. In this result, we assess the resource as neutral. 


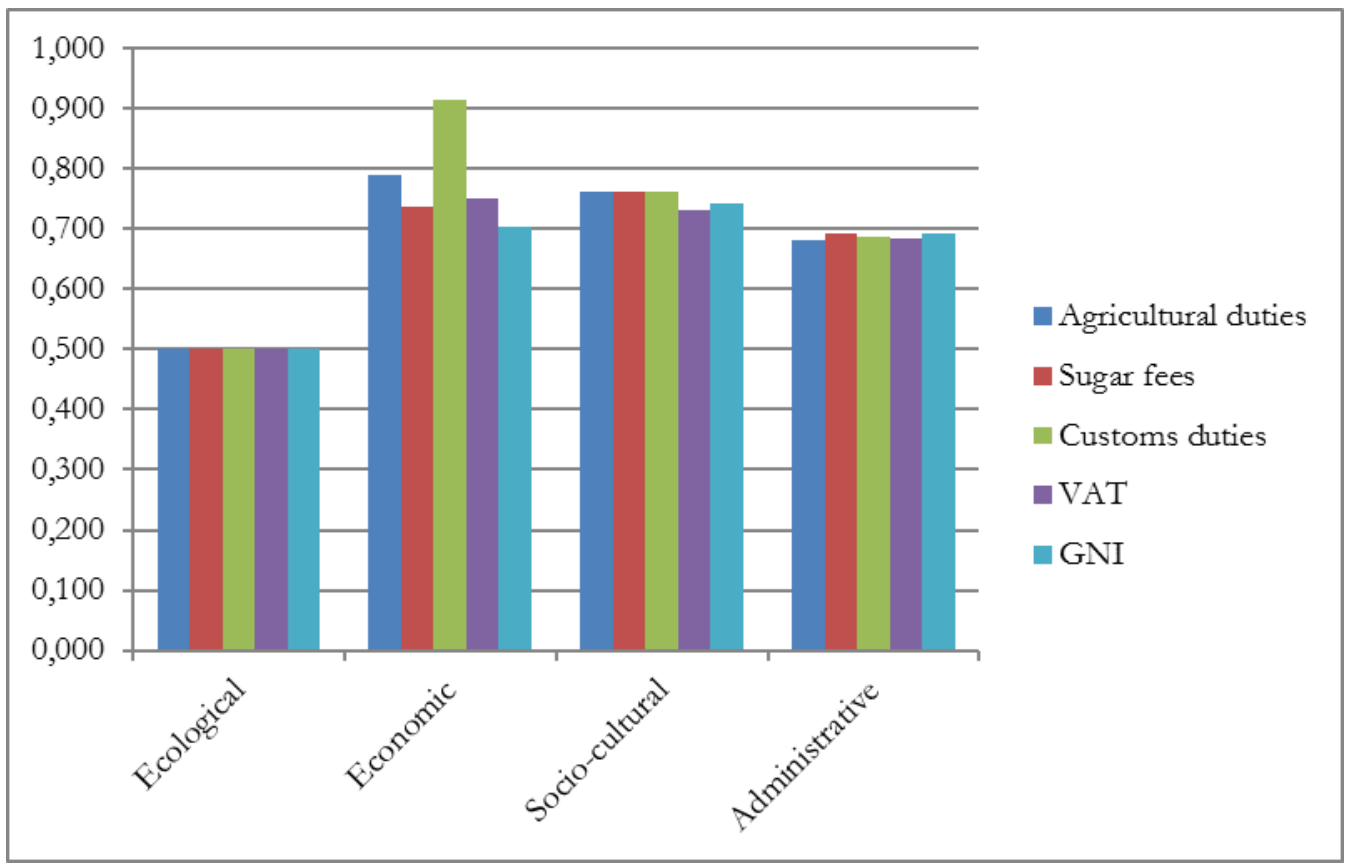

Graph 3. Sustainable development of EU own resources in the years $2000-2013$ Source: own calculations.

\subsection{EU own resources system for the years $2014-2020$}

In 2011, the Commission presented proposals of two new resources that were to go into effect from 2014: a financial transaction tax (FTT) and VAT-base tax (Commission 2011d). The Council did not accept the Commission's proposals; however, it is worth investigating how the new resources meet the criteria of sustainability. The analysis consists of carrying out the simulation of new resources and other proposed changes in budgetary conditions in the years $2000-2012$, based on our use of the following assumptions:

1) New VAT and FT'T replace the VAT and GNI resources.

The FTT, apart from increasing the financial autonomy of the European Union, is supposed to stabilize financial markets and increase the share of financial institutions in financing the costs of the post 2008 economic crises. It is imposed on the gross turnover of all financial transactions on the secondary market between commercial financial institutions (banks, investment funds etc.). The Commission proposes two minimum tax rates: $0,1 \%$ for regulated market (turnover of shares, bonds) and $0,01 \%$ for the rest of transactions. The intention is for two-thirds of the revenues collected to reinforce the EU's general budget, and rest of the amount national budgets.

New VAT is supposed to increase transparency and connection with EU citizens; and 
is a new tax based on an independent tax base and rate. Generally, the main changes, in comparison to old system, consist of a limitation of the tax base, introducing new and easier methods of tax calculation, and introducing an independent EU tax rate $(1 \%$ of tax base).

2) Administrative costs of traditional resources decrease from 25 to $10 \%$,

3) Own resources celling is reduced to $1,23 \%$ of GNI for payments and to $1,29 \%-$ for commitments,

4) A replacement of binding correction mechanisms by yearly lump sum compensations, deducted from GNI resources. The Commission proposes the following compensation amounts: for Great Britain, €3,6bn; Germany, €2,5bn; The Netherlands, €1,5bn; and Sweden, €350m.

The taxonomy rate of development for the whole projected system $\left(m_{2014}-2020\right)$ is assessed at the level of 0,350 in the scale $[0,0 ; 1,0]$. This means that the project is slightly better than the system in force in the years $2000-2013\left(m_{2000-2013}=0,331\right)$ however, overall, it is also weak with regard to sustainable development criteria.

Analysis according to the main 12 criteria results shows an unequal development of the system. Graph 4 shows that the projected system shows significant improvements in comparison to the previous one, mainly in respect of transparency, fiscal efficiency and stability, and very slightly with regard to economic integration, fairness and financial autonomy. The weaknesses of the project and reasons of them are the same as in the case of the previous system. It does not support ecology and democratic accountability. 


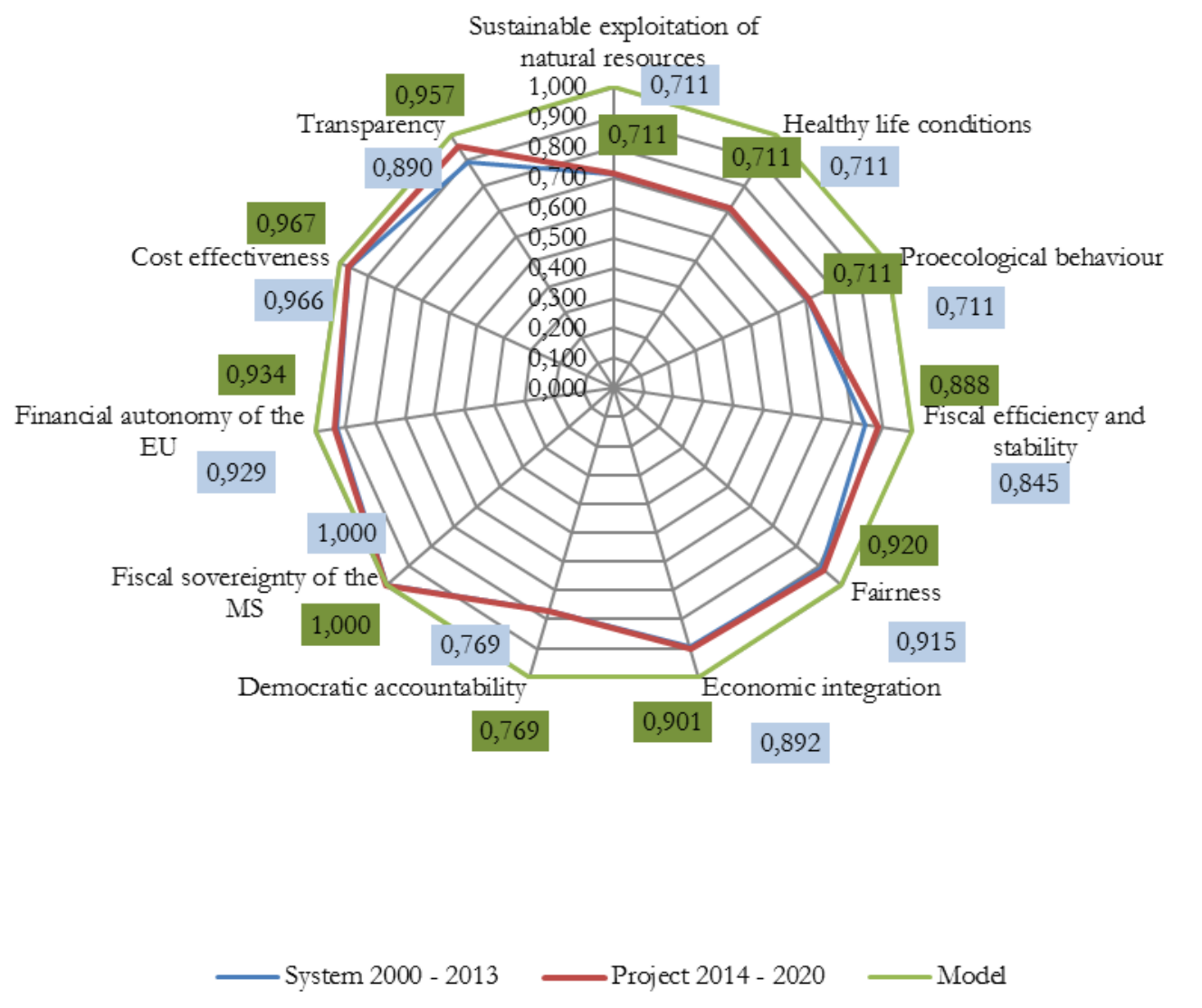

Graph 4. The EU resources system $2000-2013$ and the new EU system according to the main categories of criteria

Source: own calculations.

Once again, we assess particular resources in the projected system at a similar level to the whole system (graph 5), and find that resources support sustainable development poorly, but at an acceptable level; customs duties and FT'T received the best scores whereas the GNI resource obtained the worst. 


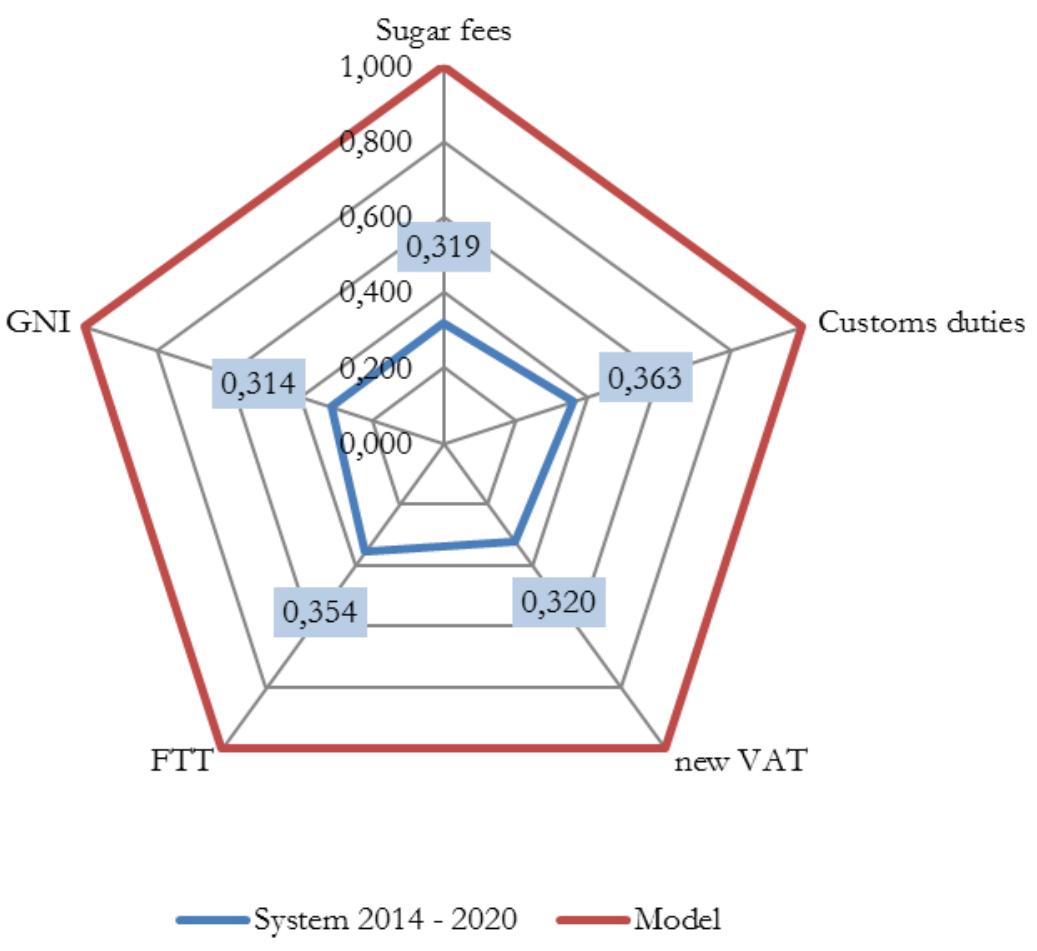

Graph 5. Assessment of EU resources for the years 2014 - 2020

Source: own calculations.

The FTT turns out to be quite transparent, cost effective, and quite fair, and works in accordance with the sovereignty of the Member States (graph 6). It also has a positive influence on the financial autonomy of the European Union and on economic integration. It is also fiscally very efficient and replaces GNI resource very effectively. However, the new resource is not very stable because of fluctuations on the financial markets. The weaknesses of the resource are typical - it does not support natural environment protection (or is neutral) and democratic accountability. 


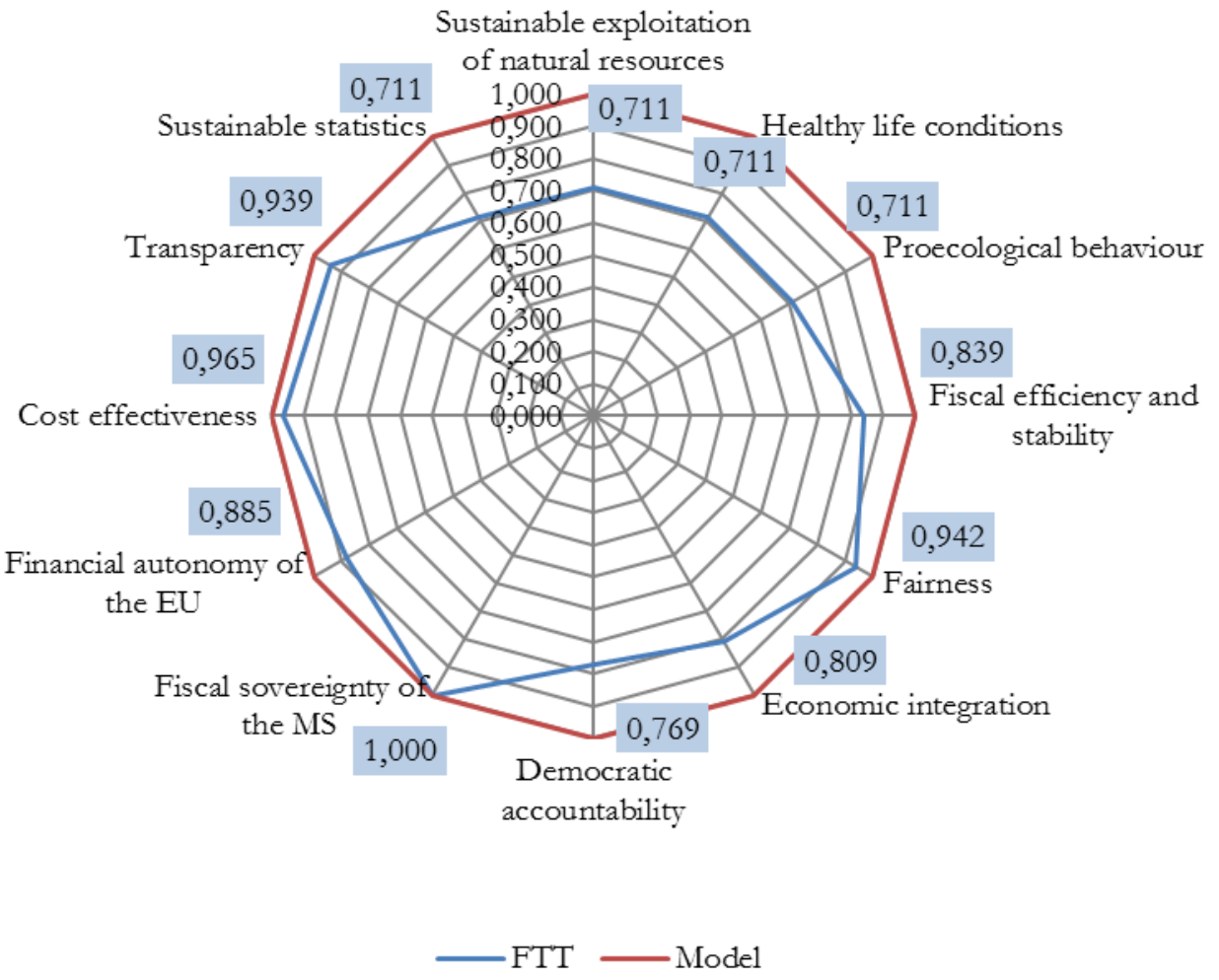

Graph 6. Assessment of FTT according to 12 main criteria

Source: own calculations

The projected resources, in comparison to the previous ones, generally improved (graph 7); all of them scored more points than the previous ones. In particular, the new VAT resource, thanks to its better transparency and better influence on financial autonomy, gains the most. Sugar fees and customs gained mainly because of a reduction in collection costs. GNI resource improved in the field of efficiency because FFT replaces it and as a result, the GNI share in total revenues is nearer the average. 


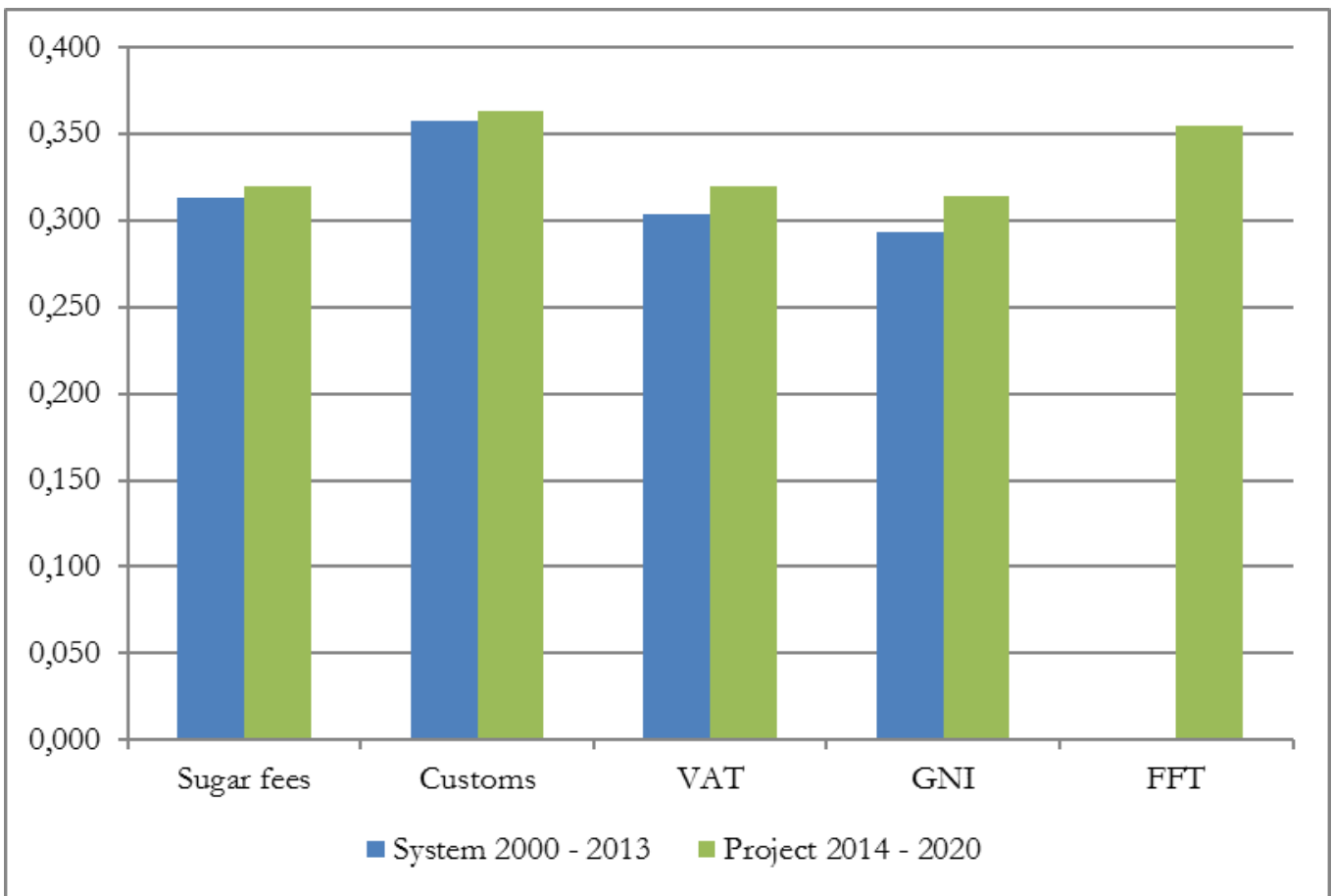

Graph 7. A Comparison of EU own resources 2000 - 2013 with the project 2014 2020

Source: own calculations.

\section{Final conclusions}

The paper presents the conception of a sustainable EU own resources system and an assessment of two EU own resources systems with regard to sustainable development criteria: the system in place between 2000 and 2013, and a system projected for the years 2014 - 2020. We base our study on multi-criteria comparison analysis and Hellwig's conception of a taxonomic development indicator.

The analysis shows that both systems, and in particular the EU own resources, support sustainable development poorly. According to table 3 the systems and resources can also be classified as poor rather than moderate. Generally, while they meet economic, sociocultural and administrative criteria at an acceptable level, they do not support (or are neutral on) natural environment protection. Formal regulations of particular EU own resources do not contain any obvious and straight solutions in this case, although it is difficult to discern any harmful effects caused by these resources. From this result, we can confirm the hypothesis formulated in the paper. 
We assess the projected system for the years 2014 - 2020, with new VAT and FTT, higher than the previous one, mainly in terms of transparency and fiscal efficiency. In order to support sustainable development both systems should be equipped with typical ecological taxes or fees (e.g. a tax on the airplane tickets, the highway fee, the $\mathrm{CO}_{2} \operatorname{tax}$ ) or with some ecological instruments, such as e.g. ecological allowances. Nevertheless, an assessment of all resources always ought to be carried out with regard to all sustainable criteria.

The methodology proposed in the paper allows for the use of both qualitative and quantitative criteria, assesses the whole system, and particular resources in different configurations, and allows for their comparison and the creation of rankings. The multicriteria comparative analysis makes the evaluations more transparent and gives results that are more objective. However, the analysis also shows some disadvantages. The most significant is that it is difficult to compare results received in different dimensions, e.g. results at the level of 29 criteria with the ones at the level of 12 criteria. The general indicator, $\left(\mathrm{m}_{i}\right)$, is the most important as it shows the quality of the whole system or the particular resource. Other indicators, (e.g. graphs 4, 6, 7), can only show relations between different criteria and indicate advantages and disadvantages of particular objects in different configurations. The other problem is that while a scoring method improves the quality of qualitative criteria, it weakens the quantitative ones, with the transformation of these results into points. Employment of different methods of distance calculation between the model and the real object can also give different results. These comments notwithstanding, while we constantly seek to improve the methodology, we maintain that multi-criteria analysis seems to be more convincing than typical qualitative assessment made by the prism of the main resources and the most conflict criteria.

* University of Roma Tre.

References

- Alesina Alberto F. and Ardagna Silvia, 2009, Large Changes in Fiscal Policy: Taxes Versus Spending, NBER Working Papers, 15438.

- Amato Giuliano and Verhofstadt Guy, 2011, 'A plan to save the euro and curb speculators', Financial Times, July 3. 
- Bibow Jörg, 2015, Making the Euro Viable: The Euro Treasury Plan, Levy Institute Working Paper, 842, July.

- De Grauwe Paul, 2011, The Governance of a fragile eurozone, CEPS Working Document, 346, May.

- De Grauwe Paul, 2013, Design Failures in the Eurozone. Can they be fixed?, European Economy Economic papers, 491, April.

- Delpla Jacques and von Weizsäcker Jakob, 2010, The Blue Bond Proposal, Bruegel.

- European Parliament, 2016, Working Document on a Budgetary Capacity for the Eurozone, February 19, DT \1086613EN.doc.

- $\quad$ Gros Daniel, 2009, A border tax to protect the global environment?, Vox, CEPR's Policy Portal, Dec. 9.

- Haug Jutta, Lamassoure Alain, Verhofstadt Guy, Gros Daniel, De Grauwe Paul, Ricard-Nihoul Gaëtane and Rubio Eulalia, 2011, Europe for Growth. For a Radical Change in Financing the EU, CEPS - Notre Europe.

- $\quad$ High Level Group on Own Resources, 2014, First Assessment Report, Bruxelles, December 17.

- Juncker Jean-Claude, Tusk Donald, Dijsselbloem Jeroen, Draghi Mario and Schulz Martin, 2015, A Deeper and Fairer Economic and Monetary Union Combining stability with fairness and democratic accountability, The Five Presidents' Report, http://ec.europa.eu/priorities/economic-monetary-union/index en.htm.

- MacDougall Donald, 1977, Report of the Study Group on Public Finance in European Integration, Brussels.

- $\quad$ Majocchi Alberto, 2013, Un Piano per l'Europa. Sviluppo sostenibile e occupazione, Franco Angeli, Milano.

- Majocchi Alberto and Missaglia Marco, 2002, Environmental taxes and border tax adjustment, Societa Italiana Economia pubblica (SIEP), Working Paper, 127.

- $\quad$ Prodi Romano and Quadrio Curzio Alberto, 2011, 'EuroUnionBond per la nuova Europa', Il Sole 24 Ore, August 23.

- $\quad$ Sapir André, 2003, An Agenda for a Growing Europe. Making the EU Economic System Deliver, Report of an Independent High-Level Study Group established on the initiative of the President of the European Commission, Brussels, July.

- Stiglitz Joseph E., Fitoussi Jean Paul., Bofinger Peter, Esping-Andersen Gøsta, Galbraith John Kenneth and Grabel Ilene, 2014, 'A Call for Policy Change in Europe', Challenge, LVII(4): 5-17.

- $\quad$ Tobin James, 1974, The New Economics One Decade Older, Princeton University Press, Princeton, NJ.

- Tobin James, 1978, ‘A Proposal for Monetary Reform', Eastern Economic Journal, XXIX(4): 519-26.

- Van Rumpuy Herman, Barroso Jean Manuel, Juncker Jean-Claude and Draghi Mario (2012), Towards a Genuine Economic and Monetary Union, 5 December, http://www.consilium.europa.eu/uedocs/cms Data/docs/pressdata/en/ec/134069.pdf.

- Varoufakis Yanis, Holland Stuart, Galbraith John Kenneth, 2013, A Modest Proposal for Resolving the Eurozone Crisis. Version 4.0, https://varoufakis.files.wordpress.com/2013/07 /a-modest-proposal-forresolving-the-eurozone-crisis-version-4-0-final1.pdf.

- Watt Andrew, 2015, Quantitative easing with bite: a proposal for conditional overt monetary financing of public investment, IMK Working Paper, 148.

- Wolff Guntram B., 2015, 'Inflation expectations and global risks: the need for ECB action', Bruegel Blog Post, October.

i Zbigniew Henryk Hellwig (1925 - 2013): Polish economist, professor, a creator of academic school of statistics, econometrics and cybernetics. In statistics, he worked out so called the Hellwig method.

ii Here is an assumption that the resources should always meet all administrative criteria, which is the base of the functioning of each public revenue system.

iii Including an additional resource comprising all miscellaneous; since 2009 agricultural duties have been incorporated into the Common Custom Tariffs. Roma Tre.

\section{References}

- Alves Rui Henrique and Cieslukowski Maciej, 2006, Financial Autonomy of the European Union after Enlargement, in FEP Working Papers, no. 217: 1-16. 
- Begg Ian, 2011, 'An EU Tax. Overdue Reform or Federalist Fantasy?', in Friedrich Ebert Stiftung, International Policy Analysis, February: 1 - 19.

- Begg Ian, Enderlein Henrik, Le Cacheux Jacques and Mrak Mojmir, 2008, Financing of the European Union Budget, Study for European Commission, Directorate General for Budget, Contract No 30-CE0122101/00-72, Final Report.

- $\quad$ Begg Ian, Grimawade Nigel, 1998, Paying for Europe, Sheffield Academic Press, Sheffield.

- Bosquet Benoit, 2000, 'Environmental Tax Reform: Does it Work? A Survay of the Empirical Evidence', Ecological Economics, no. 34: 19-32.

- Cattoir Philippe, 2004, Tax-based UE own resource: An assessment' in European Commission Taxation papers, Working paper No 1, April: 1 - 45.

- $\quad$ Cattoir Philippe, 2009, Options for an EU financing Reform, Notre Europe Policy Paper no. 38: 1 - 69.

- Cieslukowski Maciej, 2005, A rational system of the own resources for the European Community', The Poznan University of Economics Review, V(2): 5-23.

- $\quad$ Cieslukowski Maciej, 2013, Wielokryterialna ocena systemu zasobow wtasnych Unii Europejskiej, Uniwersytet Ekonomiczny w Poznaniu, Poznan.

- $\quad$ Cieslukowski, Maciej, 2014, 'Podatki i system podatkowy w ekonomii zrownowazonego rozwoju', Studia Oeconomica Posnaniensia, II(6) (267): 193-207.

- $\quad$ Commission, 1992, The System of Own Resources - Report presented by the Commission in accordance with Article 10 of the Decision on Own Resources, Brussels, COM (92) 81 final.

- Commission, 1998, Financing the European Union. Commission Report on the Operation of the Own Resources System, Brussels, COM (1998) 560 final.

- Commission, 2004, Financing the European Union. Commission report on the operation of the own resources system, COM (2004) 505 final, vols. I and II.

- Commission, 2005, 'A possible contribution based on airline tickets as a new source of financing development: technical reflections in the run up to the UN High Level Event', in Commission Staff Working Paper, SEC (2005) 1067.

- $\quad$ Commission, 2008, EU budget 2007 Financial Report, European Communities, Luxembourg.

- $\quad$ Commission, 2010, The EU Budget Review, Brussels, COM (2010) 700 final.

- Commission, 2011, Financing the EU Budget: Report on the Operation of the Own Resources System, Brussels, SEC (2011) 876 final, Annex.

- Council Decision of 29 September 2000 on the system of the European Communities' own resources, OJ L 253.

- Council Decision of 7 June 2007 on the system of the European Communities' own resources, OJ L 163.

- Council Directive 2003/96/EC of 27 October 2003 restructuring the Community framework for the taxation of energy products and electricity. 10117/06.

- Council, 2006, Review of the EU Sustainable Development Strategy - Renewed Strategy, Brussels, 9 June 2006,

- $\quad$ Environment Group, 2006, Sustainable Development: A Review of International Literature, The Centre for Sustainable Development, University of Westminster and the Law School, University of Strathclyde, Scottish Executive Social Research.

- $\quad$ Felber Christian, 2015, Change Everything: Creating an Economy for the Common Good, Zed Books, London.

- Frydman Roman, Goldberg Michel, 2011, Beyond Mechanical Markets: Asset Price Swings, Risk, and the Role of the State, Princeton University Press, New Jersey, Oxfordshire.

- Gretschmann Klaus, 1998, Reform of the Own-Resources System and Net Positions in the EU Budget, European Parliament Working Document, Budget Series- 100, October.

- Heinemann Friedrich, Mohl Philipp, Osterloh Steffen, 2008, Reform Options for the EU Own Resources System, Research Project 8/06 Commissioned by the German Federal Ministry of Finance, Mannheim.

- Hellwig Zbigniew, 1968, 'Zastosowanie metody taksonomicznej do typologii podziału krajow ze względu na poziom rozwoju oraz zasoby i strukture wykwalifikowanych kadr', Præeglad Statystyczny, XV(4): $307-327$. 
- HLGoOW, 2014, High Level Group on Own Resources, First Assessment Report, European Commission, Brussels, 17 December 2014.

- Hoerner Andrew, Bosquet Benoit, 2001, Environmental Tax Reform: The European Experience, Centre for A Sustainable Economy, Washington, DC, February.

- HoL, 2005, Future Financing of the European Union, European Union Committee, $6^{\text {th }}$ Report of Session 2004 - 05, March.

- $\quad$ Keen Martin, 1995, Objectives and Criteria of the Community's Fifth Own Resource, Study prepared for the Commission of the European Communities DG-XIX, Final Report.

- Koglin Till, 2009, Sustainable development in general and urban context: A literature review, Traffic \& Roads, Department of Technology and Society, Lund University, Bulletin 248.

- Laffan Brigid, 1997, The Finances of the European Union, Macmillan, Houndmills \& London.

- Lawn Philip (ed), 2006, Sustainable Development Indicators in Ecological Economics, Edward Elgar, Cheltenham \& Northampton.

- Le Cacheux Jacques, 2007, Funding the EU Budget with a Genuine Own Resource: The Case for a European Tax, Notre Europe Policy Paper no. 57: 1 - 41.

- Montaldo Christian R. Bueno, 2013, Sustainable Development Approaches for Rural Development and Poverty Alleviation, Yonsei University, May.

- OECD, 2004, 'Tax Administration in OECD Countries: Comparative Information Series (2004)', in Forum on Tax Administration, Centre for Tax Policy and Administration.

- OECD, 2011, 'Tax Administration in OECD and Selected Non-OECD Countries: Comparative Information Series (2010)', in Forum on Tax Administration, Centre for Tax Policy and Administration.

- $\quad$ OECD, 2001, Environmentally Related Taxes in OECD Countries. Issues and Strategies, Paris.

- ONZ, 1992, Report of the United Nations conference on Environment and Development, Rio de Janeiro, 3 - 14 June 1992, Vol. 1, Resolutions adopted by the conference, Annex II, Agenda 21, New York, pkt 1.1.

- $\quad$ Parliament, 1994, Resolution on a new system of own resources for the European Union, OJ C 128.

- Parliament, 1999, Resolution on the need to modify and reform the European Union's own resources system, OJ C 175.

- Parliament, 2007, Rezolucja z dnia 29 marca 2007 r. w sprawie prayszłosci zasobow wlasnych Unii Europejskiej, P6_TA(2007)0098.

- Parliament, 2011, Working Document No 1 on System of own resources of the European Union, $</$ Titre $><$ Commission $>$ \{BUDG $\}$ Committee on Budgets, $<$ BUDG_DT 478360.</Commission $>$.

- $\quad$ Rogall Holger, 2010, Ekonomia zrownowazonego rozwoju, Zysk i S-ka, Poznan.

- Sapir André, 2003, An Agenda for Growing Europe: Making the EU Economic System Deliver, Report of an Independent High-Level Study Group established on the initiative of the President of the European Commission, July.

- Spahn Bernd, 1993, 'The design of federal fiscal constitutions in theory and in practice', European Economy, The Economics of Community, Public Finance, 5: 541-584.

- $\quad$ Stiglitz Joseph E., 2012, The Price of Inequality. How Today's Divided Society Endangers our Future, W. W. Norton \& Company, New York \& London,

- Stodulski Wojciech (ed), 2001, Ekologiczna reforma podatkowa. System podatkony jako instrument zrownowazonego rozwoju w Polsce w pierws zej dekadzie XXI wieku, raport 2, Warszawa.

- $\quad$ Strategy 2020, 2010, A strategy for smart, sustainable and inclusive growth, Brussels, COM (2010) 2020 final.

- $\quad$ Treaty on European Union (Consolidated version 2012), OJ C 326.

- Wallart Nicolas, 1999, The Political Economy of Environmental Taxes, Edward Elgar Publishing Limited, Cheltenham. 